\title{
INVESTIGATION OF THE GLOBAL OUTCOMES OF ACUTE RESPIRATORY DISTRESS SYNDROME WITH THE EFFECT OF COVID-19 IN PUBLICATIONS: A BIBLIOMETRIC ANALYSIS BETWEEN 1980 AND 2020
}

\author{
Yayınlarda Covid-19 Etkisiyle Akut Solunum Sıkıntısı Sendromu Küresel Sonuçlarının \\ Incelenmesi: 1980-2020 Arası Bibliyometrik Analiz
}

\author{
Musa ZENGIN' ${ }^{1}$ iD, Ramazan BALDEMIR ${ }^{1}$ \\ ${ }^{1}$ Health Sciences University Ankara Atatürk Chest Diseases and Thoracic Surgery Training and Research Hospital, \\ Anesthesiology and Reanimation Clinic, ANKARA, TÜRKIYE
}

\section{ABSTRACT}

Objective: Acute respiratory distress syndrome (ARDS) is regarded as a serious complication with high mortality rates and constitutes an important health problem during the COVID-19 pandemic. Therefore, a thorough bibliometric study on ARDS is needed. In this study, it was aimed to holistically summarize the articles published on ARDS between the years 1980 and 2020 using statistical methods and bibliometric analyses.

Material and Methods: The literature was scanned using the Web of Science (WoS) database. Keywords used on WoS included "acute respiratory distress syndrome", "adult respiratory distress syndrome" and "ARDS". The search was carried out on the "titles" of the publications, and the articles obtained were bibliometrically analyzed. Linear and non-linear regression analysis was used in order to estimate the number of future studies.

Results: A total of 11.934 publications were found. Of these publications, 5402 were articles (45.3\%) on which the bibliometric analysis was performed. A high increase trend was observed in the number of publications during COVID-19. Most articles were published in the field of Critical Care Medicine $(1965,36.4 \%)$. The top four countries contributing to the literature were the USA $(1967,36.4 \%)$, Germany $(534,9.9 \%)$, France $(534,9.9 \%)$, and China $(534,9.9 \%)$. The most active 4 institutions were confirmed as theUniversity of Toronto (154), University of California San Francisco (153), University of Washington (153) and University of Harvard (151). The first 2 journals with the most publications were Critical Care Medicine (394) and Intensive Care Medicine (248).

Conclusion: In this comprehensive bibliometric study on ARDS on which the number of research increases day by day with the effect of the COVID-19 pandemic, a summarized information of 5402 articles published between 1980 and 2020 was reported. This study will be a guide for scientists and clinicians regarding the global output of ARDS.

Keywords: Acute respiratory distress syndrome, adult respiratory distress syndrome, bibliometric analysis

\section{ÖZ}

Amaç: Geçmişte ve COVID-19 pandemi sürecinde ARDS mortalite oranı yüksek olan önemli bir komplikasyon olarak karşımıza çıkmaktadır. Dolayısı ile ARDS konusunda kapsamlı bir bibliyometrik çalışmaya ihtiyaç vardır. Bu çalışmada 1980 ve 2020 yılları arasında ARDS konusunda yayınlanan makalelerin istatistiksel yöntemler ve bibliyometrik analizler kullanılarak bütünsel olarak özetlenmesi amaçlanmıştır.

Gereç ve Yöntemler: Literatür taraması Web of Science (WoS) veritabanı kullanılarak yapıldı. WoS'da arama anahtar kelimesi olarak "acute respiratory distress syndrome", "adult respiratory distress syndrome" ve "ARDS" kullanıld1. Yayınların "title" bölümünde arama yapıldı ve elde edilen makaleler bibliyometrik olarak analiz edildi. Gelecek yıllardaki yayın sayısını tahmin etmek için doğrusal ve doğrusal olmayan regresyon analizi kullanıldı.

Bulgular: Toplam 11934 yayın bulundu. Bu yayınlardan makale olan 5402 (45.3\%)'si bibliyometrik olarak analiz edildi. Yayın sayısında COVID-19 sürecinde yüksek bir artış trendi görüldü. En fazla makale Critical Care Medicine (1965, 36.4\%) araştırma alanında yayınlanmıştı. Literatüre en fazla katkı yapan ilk 4 ülke ABD (1967, 36.4\%), Almanya $(534,9.9 \%)$, Fransa $(534,9.9 \%)$ ve Çin $(534,9.9 \%)$ idi. En aktif ilk 4 kurum Toronto Üniversitesi (154), California San Francisco Üniversitesi (153), Washington Üniversitesi (153) ve Harvard Üniversitesi (151) idi. En fazla yayın yapan ilk 2 dergi Critical Care Medicine (394) ve Intensive Care Medicine (248) idi.

Sonuç: COVID-19'un da etkisiyle her geçen gün araştırma sayısı artan ARDS konusunda yaptığımız bu kapsamlı bibliyometrik çalışmada 1980-2020 yılları arasında yayımlanmış 5402 makalenin bir özet bilgisini paylaştık. Bu makale ARDS global çıktıları hakkında bilim insanları ve klinisyenlere faydalı bir rehber olacaktır.

Anahtar Kelimeler: Akut solunum sikintısi sendromu, bibliyometrik analiz, yetişkin solunum sikıntısı sendromu 


\section{INTRODUCTION}

ARDS is a severe form of respiratory failure with significant impact on the morbidity and mortality of critical care patients (1). With high mortality and morbidity rates, acute respiratory distress syndrome (ARDS) is an acute respiratory failure involving both lungs and is characterized by hypoxemia despite oxygen treatment. General mortality rates ranged from 11 to $87 \%$ in studies including subjects with ARDS of all etiologies (1). ARDS was defined by the AmericanEuropean Consensus Conference (AECC) in 1991 and later revised by the Berlin definition as a result of an expert panel in 2011 (an initiative of the European Society of Intensive Care Medicine approved by the American Thoracic Society and the Society of Critical Care Medicine). Three ARDS categories were proposed based on the degree of hypoxemia in the Berlin definition: mild $(200 \mathrm{~mm} \mathrm{Hg}<\mathrm{PaO} 2 / \mathrm{FIO} 2 \leq 300 \mathrm{~mm}$ $\mathrm{Hg}$ ), moderate (100 mm Hg < $\mathrm{PaO} 2 / \mathrm{FIO} 2 \leq 200 \mathrm{~mm} \mathrm{Hg}$ ), and severe $(\mathrm{PaO} 2 / \mathrm{FIO} 2 \leq 100 \mathrm{~mm} \mathrm{Hg})(2)$. The Berlin definition of ARDS both improves the predictor validity of the AECC definition regarding mortality and clarifies the conceptual model of ARDS with its diagnostic criteria and severity spectrum (3).

Fundamentally, ARDS is a complication of another disease. With the onset of the coronavirus pandemic in China at the end of 2019, ARDS attracted the clinicians' attention one more time. In a study conducted in China, ARDS has been determined as the most commonly encountered complication $(61.1 \%)$ in patients followed in intensive care units due to coronavirus pneumonia (4). Nonetheless, ARDS manifests as a result of severe pulmonary infections, aspiration pneumonia, sepsis, severe trauma, severe burns, pancreatitis, drug reactions, and inhalation injuries (5). Mechanical ventilation is a life-saver in the treatment of ARDS. When response to conventional therapies is not achieved, ECMO (extracorporeal membrane oxygenation) can be applied as a treatment option (6).
Bellani et al. (2016) has concluded that ARDS is inadequately recognized, insufficiently treated and related to high mortality rates in a study on epidemiology and mortality in patients with ARDS conducted in 50 countries and 459 intensive care units (7). According to the study findings, $10.4 \%$ of ICU admissions and $23.4 \%$ of the patients requiring mechanical ventilation have resulted from ARDS. Besides, prevalence has been found as $30.0 \%$, 46.6\%, and $23.4 \%$ in mild, moderate, and severe ARDS, respectively. Hospital mortality has been detected as $34.9 \%$ in mild ARDS, $40.3 \%$ in moderate ARDS, and $46.1 \%$ in severe ARDS (7).

Although revisions and developments have been made in the diagnosis and treatment of ARDS with a high mortality rate, there is still clinical debate. Consequently, scientists must research ARDS to reach the current data and information on ARDS swiftly, the most read and cited publications, and the centers and authors sharing information the most, which leads to the need for a thorough bibliometric study on ARDS.

Bibliometry is the analysis of scientific publications, notably articles, using statistical methods (8-10). Bibliometric investigations bring out studies with the most citations and impact level, trend topics that are researched the most, active institutions, active authors, contributing countries, and the international cooperation among them on a specific subject or research area (1114). Thanks to the bibliometric studies presenting a summary of thousands of articles, researchers spare time in literature review and can reach the subject they are looking for much faster (15). In the literature, bibliometric research on medicine's various important topics has been made recently (8-19).

Therefore, a thorough bibliometric study on ARDS is needed. This study aimed to holistically summarize the articles published on ARDS between the years 1980 and 2020 using statistical methods and bibliometric analyses. 


\section{MATERIALS AND METHODS}

The literature was scanned using the Web of Science (WoS) database. Keywords used on WoS included "acute respiratory distress syndrome," "adult respiratory distress syndrome," and "ARDS." The search was carried out on the "titles" of the publications, and thus all publications between 1980 and 2020 using one of these keywords on their title were reached (access date: 01.01.2021). Codes for the researchers to access similar documents: (title: ("acute respiratory distress syndrome") or title: ("adult respiratory distress syndrome") or title: ("ARDS") refined by: document types: (article) Timespan: 1980-2020. Indexes: SCIExpanded, SSCI, A\&HCI, CPCI-S, CPCI-SSH, BKCI-S, $B K C I-S S H, E S C I)$. The articles obtained were analyzed bibliometrically. VOSviewer (Version 1.6.15) package program was used for keyword analyses, citation and cocitation analyses, and bibliometric mapping (20). (http://lert.co.nz/map/) website was used for the drawing of the world map. Statistical analyses were conducted on SPSS (Version 22.0, SPSS Inc., Chicago, IL, the USA) package program. The Kolmogorov-Smirnov test assessed the normal distribution of the data. Linear and non-linear regression analysis was used to estimate the number of further publications. $P<0.05$ was accepted as statistically significant.

\section{RESULTS}

A total of 11.934 publications on ARDS were found between the years 1980 and 2020. Of these publications, 5402 (45.3\%) were articles, 3129 (26.2\%) were meeting abstracts, $1136(9.5 \%)$ were letters, 1011 (8.5\%) were editorial materials, $880(7.4 \%)$ were reviews, 402 (3.4\%) were Proceedings Papers. The rest were in different publication types (Notes 93, Corrections 80, Early Accesses 57, Book Chapters 51, News Items 13, Correction Additions 11, Book Reviews 5).
In the study, 5402 articles were analyzed bibliometrically. Five thousand ninety-one (94.2\%) of the 5402 articles were in English, and the rest were in German (142), French (103), Spanish (43), Turkish (7), Korean (4), Russian (4), Portuguese (3), Swedish (3), Italian (2), Polish (2), Icelandic (1), Japanese (1), and Serbian (1).

The total number of citations received by 5402 articles was 202.128, and the average number of citations per article was 37.42, and the $\mathrm{h}$ index was 188 .

Active Research Areas

The top 10 research areas with the highest number of studies on ARDS were the following: Critical Care Medicine (1965, 36.4\%), Respiratory System (1302, 24.1\%), General Internal Medicine (647, 12\%), Anesthesiology (417, 7.7\%), Surgery (391, 7.2\%), Medicine Research Experimental (253, 4.7\%), Pediatrics (197, 3.6\%), Cardiac Cardiovascular Systems $(175,3.2 \%)$, Immunology (134, 2.5\%), and Pharmacology Pharmacy (130, 2.4\%).

Development of Publications

Figure 1 shows the distributions of the articles by years. The regression analysis results used to estimate the number of further publications between 2021 and 2025 were shown in Figure 1. According to the results of the regression analysis, it was estimated that 477 articles (CI\%: 429-524) would be published in 2021 and 503 articles (CI\%: 450-556) in 2025 (Fig. 1). On the nonlinear regression analysis, 473 articles were estimated to be published in 2021 regarding the cubic model.

Active Countries

Figure 2 shows the distribution of world countries publishing the highest number of articles. The first 20 countries publishing articles the most on ARDS were found as follows: the USA (1967, 36.4\%), Germany (534, 9.9\%), China (534, 9.9\%), France (534, 9.9\%), Italy $(355,6.6 \%)$, the UK $(324,6 \%)$, Canada (301, $5.6 \%)$, Japan $(227,4.2 \%)$, Spain $(210,3.9 \%)$, the 
Netherlands (156, 2.9\%), Brazil (149, 2.8\%),

Switzerland (147, 2.7\%), Taiwan (128, 2.4\%), India (116, 2.1\%), Belgium (101, 1.9\%), Sweden (101, 1.9\%), South Korea (99, 1.8\%), Australia (79, 1.5\%), Austria $(74,1.4 \%)$, and Turkey $(68,1.3 \%)$ (Fig. 3a). Out of the 90 countries publishing articles on ARDS, Figure 3 presents the international cooperation density map between 57 countries that co-operate and produce at least 5 articles.

\section{Active Authors}

The first ten authors publishing the highest number of articles (more than 50 articles) on ARDS were found respectively as Matthay MA (97 articles), Thompson BT (80 articles), Gattinoni L (64 articles), Brochard L (63 articles), Pesenti A (62 articles), Hudson LD (57 articles), Pelosi P (56 articles), Calfee CS (55 articles), Papazian L (55 articles), and Slutsky AS (55 articles).

\section{Active Institutions}

The most active universities publishing more than 50 articles on ARDS were determined respectively as the University of Toronto (154 articles), University of California San Francisco (153 articles), University of Washington (153 articles), Harvard University (151 articles), Massachusetts General Hospital (121 articles), University of Milan (104 articles), Vanderbilt University (98 articles), University of Colorado (96 articles), University of Pennsylvania (93 articles), University of Michigan (84 articles), University of Sao Paulo (81 articles), St Michael's Hospital (69 articles), Johns Hopkins University (66 articles), University of Pittsburgh (64 articles), University of Utah (63 articles), Mayo Clinic (58 articles), University of Texas (55 articles), and University of Maryland (52 articles).
Active Journals

There were 62 journals out of 1098 ARDS-related journals publishing 15 and more than 15 articles on ARDS. Table 1 presents these active journals, the total number of most cited journals citations received by the journals, and the total number of citations per article. Moreover, Figure 4 shows the average citation network visualization map carried out among these 62 journals.

\section{Citation Analysis}

Table 2 demonstrates the first most cited 25 articles on ARDS according to the total number of citations. The last column of Table 2 also presents the average number of citations received by the articles per year.

Co-citation Analysis

In the "references" section of the articles analyzed, there were a total of 73.975 published studies that were cited by all of the articles. The most effective first 11 studies that received more than 300 citations were found respectively as Bernard (1994) (Number of co-citations, 1311), Ranieri (2012) (1148), Brower (2000) (982), Murray (1988) (669), Ashbaugh (1967) (663), Ware (2000) (545), Rubenfeld (2005) (460), Bellani (2016) (419), (Amato) (1998) (391), Knaus (1985) (316), and Guerin (2013) (305) (1,2,6,7,21-27).

Keyword Analysis and Trend Topics

Five thousand eight hundred and sixty-four different keywords were used in 5401 articles. Out of these keywords, 81 keywords used in at least 20 separate articles are presented in Table 3. Cluster analysis between these keywords was shown in Figure 5. Trend visualization network map is given in Figure 6a, and citation network map on Figure $6 b$. 
Table 1: Active journals on ARDS

\begin{tabular}{|c|c|c|c|c|c|c|c|}
\hline Journals & $\mathbf{R C}$ & $\mathbf{C}$ & $\mathbf{A C}$ & Journals & $\mathbf{R C}$ & $\mathbf{C}$ & $\mathbf{A C}$ \\
\hline Critical Care Medicine & 394 & 20981 & 53.3 & Internal Medicine & 22 & 181 & 8.2 \\
\hline American Journal of Respiratory And & 214 & 27097 & 126.6 & Experimental and Therapeutic & 22 & 113 & 5.1 \\
\hline Critical Care Medicine & & & & Medicine & & & \\
\hline Intensive Care Medicine & 248 & 13252 & 53.4 & Lancet & 20 & 2879 & 144.0 \\
\hline American Review of Respiratory & 87 & 9909 & 113.9 & International Journal of Clinical and & 22 & 13 & 0.6 \\
\hline Disease & & & & Experimental Medicine & & & \\
\hline Chest & 221 & 14134 & 64.0 & Journal of Intensive Care Medicine & 21 & 122 & 5.8 \\
\hline Critical Care & 158 & 3993 & 25.3 & Lancet Respiratory Medicine & 21 & 3486 & 166.0 \\
\hline Journal of Critical Care & 102 & 1558 & 15.3 & Anaesthesia and İntensive Care & 20 & 237 & 11.9 \\
\hline Respiratory Care & 75 & 1295 & 17.3 & Annals of Thoracic Surgery & 20 & 573 & 28.7 \\
\hline Anesthesiology & 68 & 3321 & 48.8 & Scientific Reports & 20 & 162 & 8.1 \\
\hline Plos One & 66 & 688 & 10.4 & Asaio Journal & 19 & 151 & 7.9 \\
\hline Annals of Intensive Care & 62 & 555 & 9.0 & Burns & 19 & 264 & 13.9 \\
\hline European Respiratory Journal & 61 & 2258 & 37.0 & Revue Des Maladies Respiratoires & 19 & 31 & 1.6 \\
\hline Journal of Trauma-Injury Infection & 48 & 2418 & 50.4 & Schweizerische Medizinische & 19 & 54 & 2.8 \\
\hline and Critical Care & & & & Wochenschrift & & & \\
\hline ActaAnaesthesiologicaScandinavica & 54 & 1029 & 19.1 & BMC Anesthesiology & 18 & 79 & 4.4 \\
\hline Clinics in Chest Medicine & 54 & 1913 & 35.4 & Anesthesia and Analgesia & 17 & 454 & 26.7 \\
\hline Shock & 46 & 1084 & 23.6 & Chinese Medical Journal & 17 & 139 & 8.2 \\
\hline AnnalesFrancaises D Anesthesie Et & 16 & 42 & 2.6 & Annals of the American Thoracic & 17 & 261 & 15.4 \\
\hline De Reanimation & & & & Society & & & \\
\hline Pediatric Critical Care Medicine & 44 & 1165 & 26.5 & Heart \& Lung & 17 & 110 & 6.5 \\
\hline Anaesthesist & 38 & 336 & 8.8 & Medicine & 25 & 92 & 3.7 \\
\hline Minerva Anestesiologica & 37 & 714 & 19.3 & Journal of Surgical Research & 17 & 335 & 19.7 \\
\hline Thorax & 37 & 1604 & 43.4 & Perfusion-UK & 17 & 105 & 6.2 \\
\hline Journal of Thoracic Disease & 32 & 172 & 5.4 & Respiration & 17 & 215 & 12.6 \\
\hline New England Journal of Medicine & 31 & 24327 & 784.7 & Southern Medical Journal & 17 & 223 & 13.1 \\
\hline Bmc Pulmonary Medicine & 29 & 263 & 9.1 & Respirology & 16 & 277 & 17.3 \\
\hline American Journal of Physiology- & 30 & 1047 & 34.9 & Journal of Trauma and Acute Care & 25 & 517 & 20.7 \\
\hline Lung Cellular and Molecular & & & & Surgery & & & \\
\hline \multicolumn{8}{|l|}{ Physiology } \\
\hline Jama-Journal of the American & 29 & 14419 & 497.2 & Journal of the Formosan Medical & 16 & 127 & 7.9 \\
\hline Medical Association & & & & Association & & & \\
\hline British Journal of Anaesthesia & 27 & 534 & 19.8 & Radiology & 15 & 802 & 53.5 \\
\hline Pediatric Pulmonology & 29 & 384 & 13.2 & Surgery & 16 & 631 & 39.4 \\
\hline American Journal of Respiratory Cell & 15 & 444 & 29.6 & International Journal of Artificial & 16 & 139 & 8.7 \\
\hline and Molecular Biology & & & & Organs & & & \\
\hline Critical Care Clinics & 27 & 544 & 20.1 & Resuscitation & 15 & 317 & 21.1 \\
\hline Respiratory Research & 26 & 440 & 16.9 & MedicinaIntensiva & 15 & 58 & 3.9 \\
\hline
\end{tabular}

RC: Record count C: Number of citation, AC: Average citation per document 
Table 2: Top 25 most cited articles according to total citations on ARDS

\begin{tabular}{|c|c|c|c|c|c|}
\hline No & Author & Journal & PY & TC & $\overline{\mathrm{AC}}$ \\
\hline 1 & Brower RG et al. & New England Journal of Medicine & 2000 & 6270 & 298.6 \\
\hline 2 & Ranieri VM et al. & JAMA-Journal of the American Medical Association & 2012 & 3555 & 395 \\
\hline 3 & Amato MBP et al. & New England Journal of Medicine & 1998 & 2158 & 93.8 \\
\hline 4 & $\mathrm{Xu} \mathrm{Z}$ et al. & Lancet Respiratory Medicine & 2020 & 1756 & 1756 \\
\hline 5 & Rossaint $\mathrm{R}$ et al. & New England Journal of Medicine & 1993 & 1349 & 48.2 \\
\hline 6 & Brower RG et al. & New England Journal of Medicine & 2004 & 1329 & 78.2 \\
\hline 7 & Bellani $\mathrm{G}$ et al. & JAMA-Journal of the American Medical Association & 2016 & 1328 & 265.6 \\
\hline 8 & Guerin $\mathrm{C}$ et al. & New England Journal of Medicine & 2013 & 1246 & 155.8 \\
\hline 9 & Herridge MS et al. & New England Journal of Medicine & 2003 & 1230 & 68.3 \\
\hline 10 & Ranieri VM et al. & JAMA-Journal of the American Medical Association & 1999 & 1199 & 54.5 \\
\hline 11 & Wu C et al. & JAMA Internal Medicine & 2020 & 1190 & 1190 \\
\hline 12 & Papazian L et al. & New England Journal of Medicine & 2010 & 1190 & 108.2 \\
\hline 13 & Herridge MS et al. & New England Journal of Medicine & 2011 & 1175 & 117.5 \\
\hline 14 & Davies A et al. & JAMA-Journal of the American Medical Association & 2009 & 965 & 80.4 \\
\hline 15 & Amato MBP et al. & New England Journal of Medicine & 2015 & 813 & 135.5 \\
\hline 16 & Montgomery AB et al. & American Review of Respiratory Disease & 1985 & 812 & 22.6 \\
\hline 17 & Meade MO et al. & JAMA-Journal of the American Medical Association & 2008 & 786 & 60.5 \\
\hline 18 & Gattinoni L et al. & New England Journal of Medicine & 2006 & 782 & 52.1 \\
\hline 19 & Fouchier RAM et al. & $\begin{array}{l}\text { Proceedings of the National Academy of Sciences of the } \\
\text { United States of America }\end{array}$ & 2004 & 781 & 45.9 \\
\hline 20 & Briel $\mathrm{M}$ et al. & JAMA-Journal of the American Medical Association & 2010 & 746 & 67.8 \\
\hline 21 & Steinberg KP et al. & New England Journal of Medicine & 2006 & 732 & 48.8 \\
\hline 22 & Mercat A et al. & JAMA-Journal of the American Medical Association & 2008 & 728 & 56 \\
\hline 23 & Fowler AA et al. & Annals of Internal Medicine & 1983 & 688 & 18.1 \\
\hline 24 & Weiland JE et al. & American Review of Respiratory Disease & 1986 & 636 & 18.2 \\
\hline 25 & Hudson LD et al. & $\begin{array}{l}\text { American Journal of Respiratory and Critical Care } \\
\text { Medicine }\end{array}$ & 1995 & 634 & 24.4 \\
\hline
\end{tabular}

PY: Publication year, TC: Total citation, AC: Average citations per year 
Table 3: The most frequently used trend keywords on ARDS

\begin{tabular}{|c|c|c|c|}
\hline 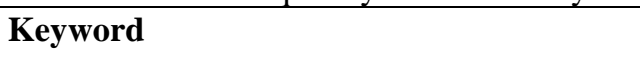 & $\mathbf{O}$ & Keyword & $\mathbf{O}$ \\
\hline acute respiratory distress syndrome & 1514 & bronchoalveolar lavage & 37 \\
\hline ARDS & 798 & epidemiology & 37 \\
\hline mechanical ventilation & 386 & hypoxemia & 37 \\
\hline acute lung injury & 371 & computed tomography & 36 \\
\hline mortality & 172 & pediatric acute respiratory distress syndrome & 35 \\
\hline adult respiratory distress syndrome & 165 & prone positioning & 33 \\
\hline extracorporeal membrane oxygenation & 152 & intensive care & 32 \\
\hline sepsis & 150 & biomarkers & 31 \\
\hline acute respiratory distress syndrome (ARDS) & 119 & driving pressure & 30 \\
\hline respiratory distress syndrome & 115 & pulmonary hypertension & 30 \\
\hline adult & 103 & risk factors & 30 \\
\hline positive end-expiratory pressure & 92 & hypoxia & 28 \\
\hline pneumonia & 90 & pediatric & 28 \\
\hline ECMO & 87 & septic shock & 28 \\
\hline prone position & 85 & ventilation & 28 \\
\hline respiratory failure & 81 & high-frequency oscillatory ventilation & 27 \\
\hline outcome & 80 & biomarker & 26 \\
\hline inflammation & 76 & echocardiography & 26 \\
\hline critical care & 71 & meta-analysis & 26 \\
\hline lung injury & 66 & airway pressure release ventilation & 25 \\
\hline COVID-19 & 63 & corticosteroids & 25 \\
\hline ventilator-induced lung injury & 62 & recruitment maneuver & 25 \\
\hline nitric oxide & 58 & diagnosis & 24 \\
\hline respiratory distress syndrome, adult & 57 & high-frequency ventilation & 24 \\
\hline oxygenation & 55 & intensive care unit & 24 \\
\hline prognosis & 54 & lung protective ventilation & 24 \\
\hline pulmonary edema & 51 & multiple organ failure & 24 \\
\hline acute respiratory failure & 50 & SARS-COV-2 & 24 \\
\hline critical illness & 50 & protective ventilation & 23 \\
\hline surfactant & 49 & survival & 23 \\
\hline trauma & 47 & diffuse alveolar damage & 22 \\
\hline cytokines & 46 & electrical impedance tomography & 22 \\
\hline peep & 46 & lipopolysaccharide & 22 \\
\hline ALI & 44 & intensive care unit & 21 \\
\hline gas exchange & 44 & lung recruitment & 21 \\
\hline tidal volume & 44 & apoptosis & 20 \\
\hline lung & 42 & berlin definition & 20 \\
\hline children & 41 & outcomes & 20 \\
\hline pediatrics & 39 & transpulmonary pressure & 20 \\
\hline respiratory mechanics & 38 & & \\
\hline
\end{tabular}

O: Number of occurrences 


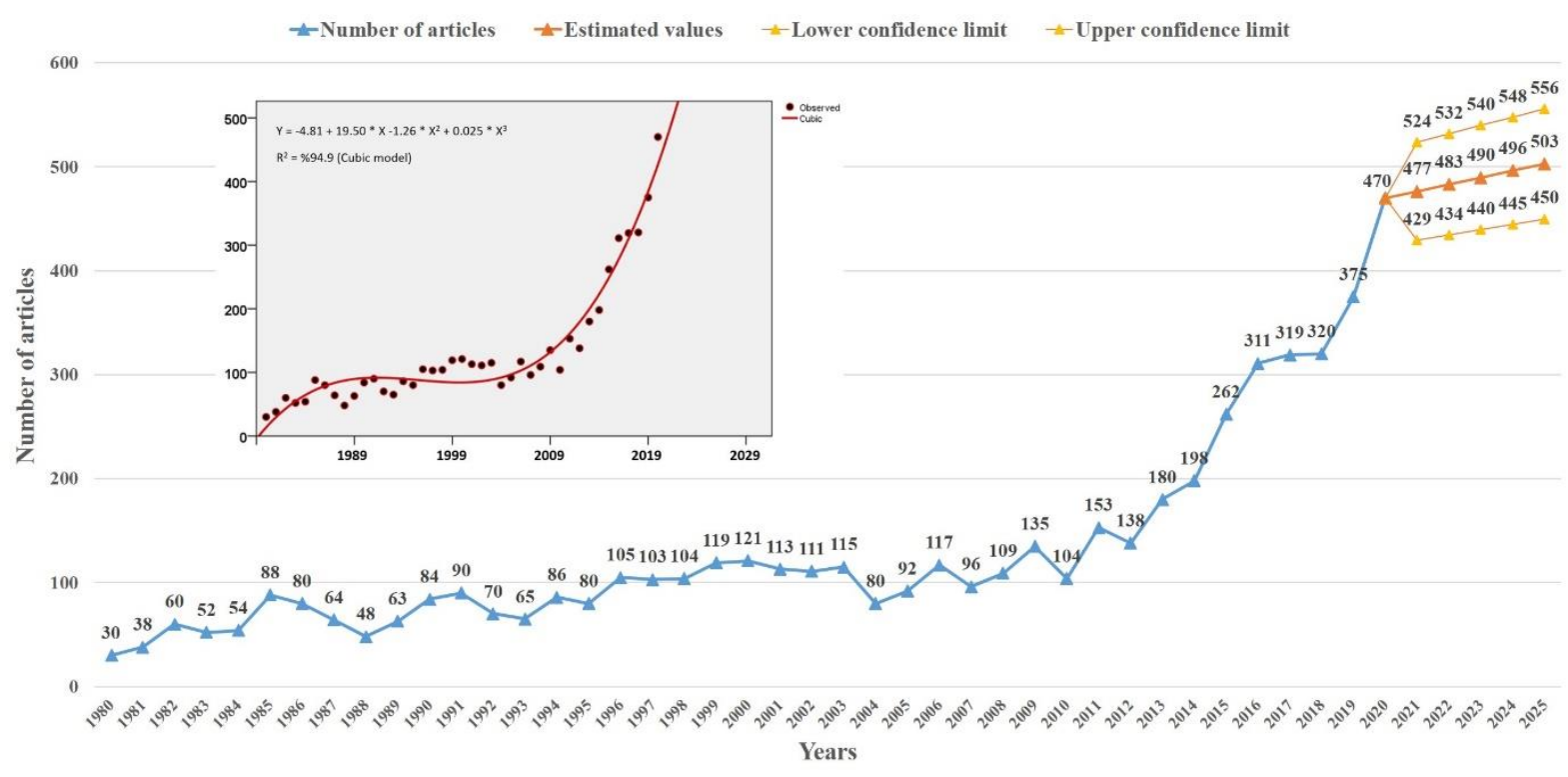

Figure 1: The distribution of ARDS articles by years and the regression line for the estimation of the number of publications in the following years

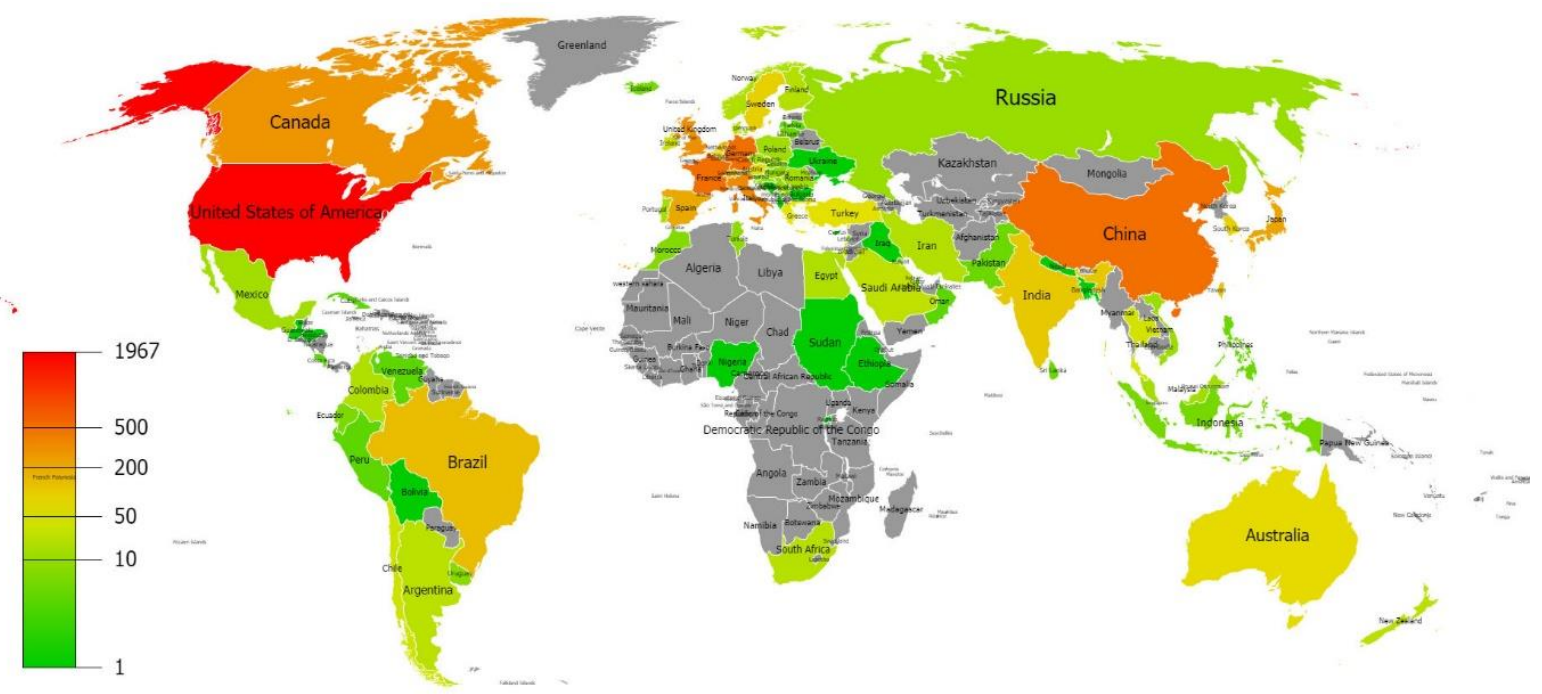

Figure 2: World map showing the distribution of articles on ARDS by Country Footnote: The number of articles for countries increases from green to red in the indicator at the bottom left of the figure 
a.

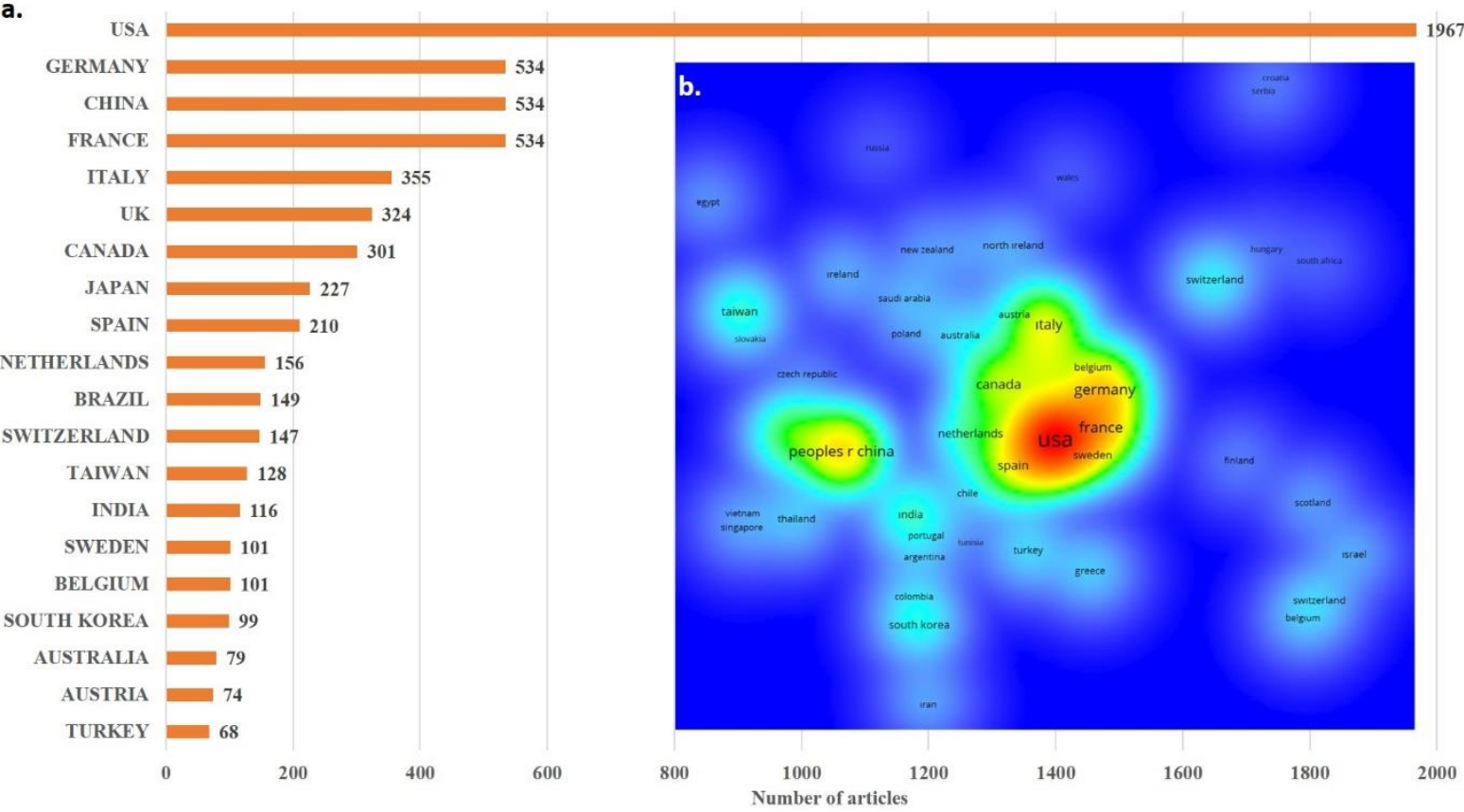

Figure 3: (a) Bar chart for the top 20 countries producing the most articles on ARDS (b) Density visualization map for international cooperation of worldwide countries on ARDS

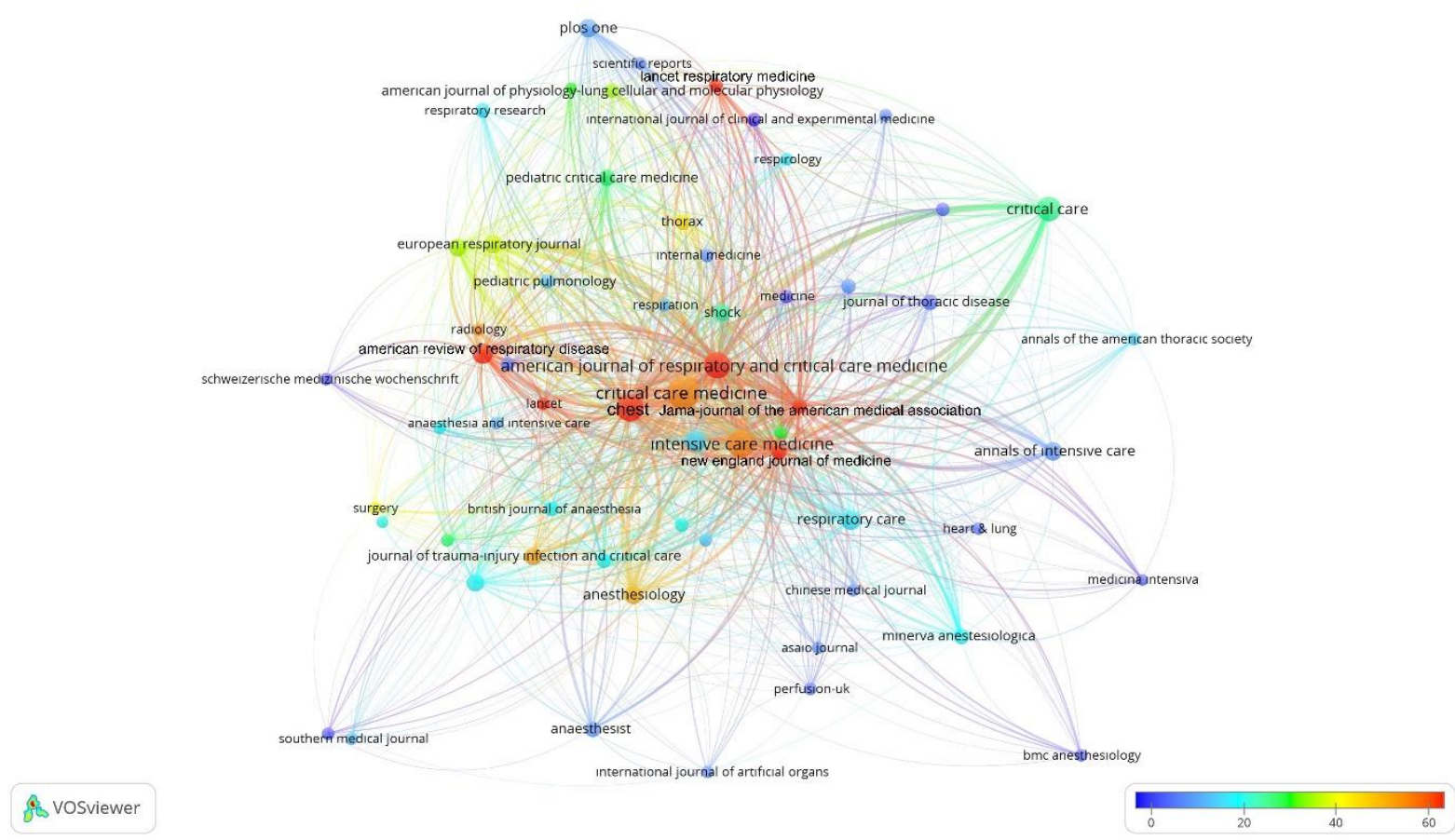

Figure 4: Network visualization map for citation analysis of journals that produce publications on ARDS Footnote: The number of citations from blue to red (blue-green-yellow-red) increases, the size of the circle area indicates that the number of articles produced is greater 


\section{\& vosviewer}

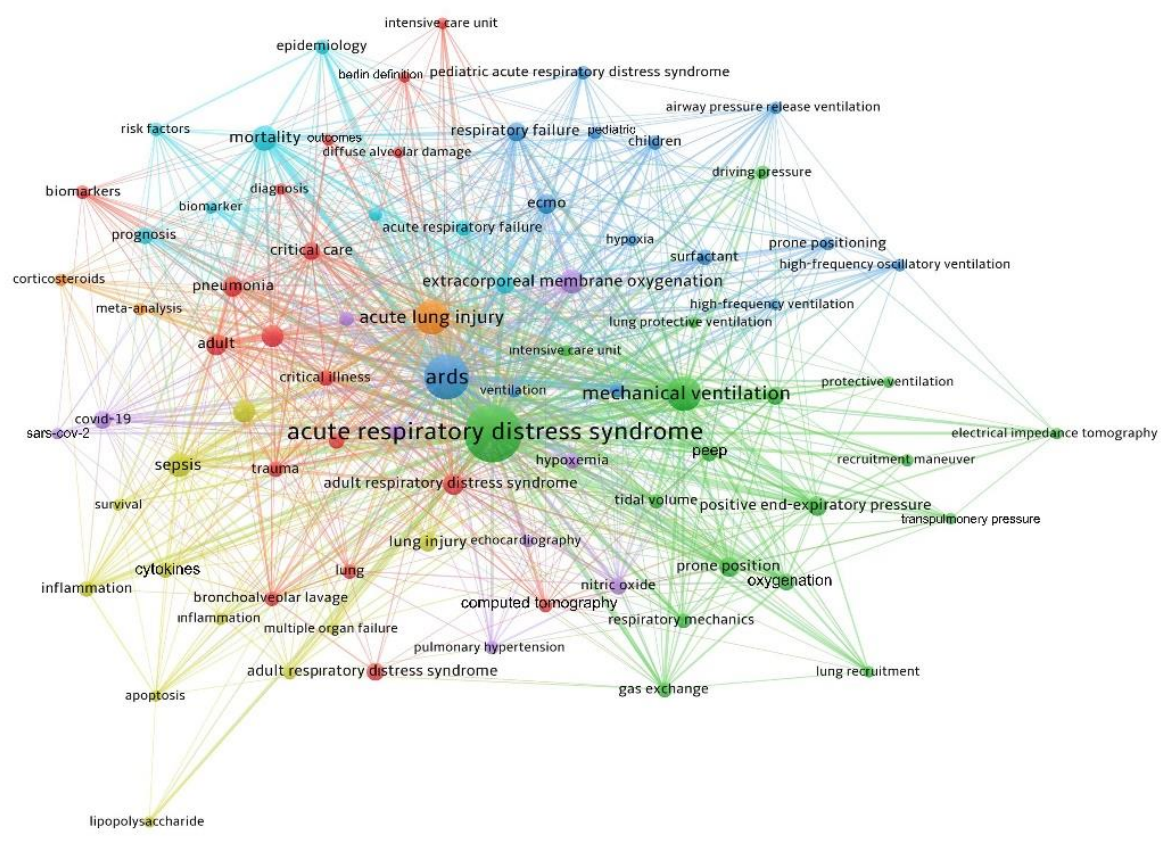

Figure 5: Network visualization map for cluster analysis based on keyword analysis on ARDS Footnote: The colors indicate the clusters, the size of the circle area suggests that the number of articles produced is greater, and the thickness of the lines indicates the strength of a relationship
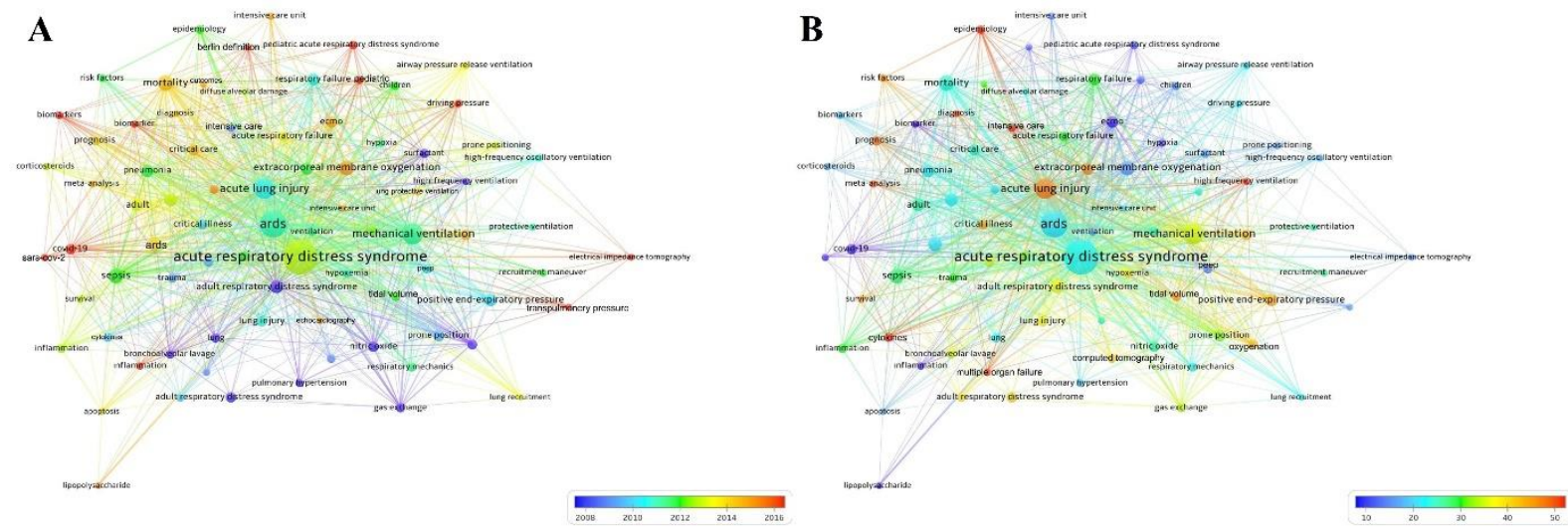

Figure 6: (a) Network visualization map for trends based on keyword analysis on ARDS Footnote: Indicator shows current articles from blue to red, the size of the circle area indicates that the number of articles produced is greater (b) Network visualization map for citations based on keyword analysis on ARDS Footnote: The number of citations from blue to red (blue-green-yellow-red) increases, the size of the circle area indicates that the number of articles produced is greater 


\section{DISCUSSION}

Our findings indicated that the number of articles published on ARDS increased with every passing day. Less than 100 articles per year had been published until 1996. Articles between the range of 100-200 had been published every year between 1996 and 2013. The number of articles, which was limited initially, increased significantly and reached 470 in 2020 . According to the regression analysis results, this increasing trend is believed to continue in the upcoming years. It is considered that the increase in 1996 resulted from the ARDS definition following the American-European Consensus, and the increase in 2013 resulted from the revised definition of Berlin ARDS. The remarkable rise in the number of articles, particularly in the last two years, maybe related to ARDS development due to COVID-19. ARDS is the most common complication among the reasons for admission to the intensive care unit due to COVID-19 (4). The pandemic is found to be instrumental in publication productivity on ARDS. The number of articles on ARDS during the pandemic has increased due to the rise in the prevalence of ARDS in patients followed for COVID-19 pneumonia and concordantly in the requirement of intensive care in these patients. While the risk factors and clinical manifestations of ARDS that develop due to COVID-19 are not yet fully identified, it is considered that it has a more different process and clinical course than the conventional ARDS $(28,29)$.

A significant correlation has been established between the economic potential of a country and its publication productivity in several bibliometric research in the literature (12,13). Our study also detected that the countries publishing the highest number of articles on ARDS are developed countries or have a strong economy, which made us consider that the most important factor in publication productivity is the level of development.
The journals with the most publications were found respectively as the Critical Care Medicine, Intensive Care Medicine, Chest, American Journal of Respiratory and Critical Care Medicine, Critical Care, Journal of Critical Care, American Review of Respiratory Disease, Respiratory Care, and Anesthesiology. We suggest these journals to authors wishing to do research and publish articles on ARDS. When the journals generating at least 15 articles were evaluated in regard to the number of citations per articles, the journals receiving an average of 50 and over 50 citations were respectively found to be the New England Journal of Medicine, Jama-Journal of the American Medical Association, Lancet Respiratory Medicine, Lancet, American Journal of Respiratory and Critical Care Medicine, American Review of Respiratory Disease, Chest, Radiology, Intensive Care Medicine, Critical Care Medicine, Journal of Trauma-Injury Infection and Critical Care, and Anesthesiology. These journals stand out as highimpact journals. We suggest these journals to authors who wish to reach a higher impact with their articles.

When the articles analyzed were reviewed according to the total number of citations, the first most cited article was determined as the study by Brower et al. (2000) (AcuteRespiratoryDistressSyndrome Network) titled "Ventilation with lower tidal volumes as compared with traditional tidal volumes for acute lung injury and the acute respiratory distress syndrome" and published in the New England Journal of Medicine (6). The following most influential study was that of Ranieri et al. (2012) (ARDS Definition Task Force) that constituted the Berlin definition of ARDS and was published in JAMA (2). The third most cited article was the study by Amatove et al. (1998) titled "Effect of a protective-ventilation strategy on mortality in the acute respiratory distress syndrome" and published in the New England Journal of Medicine (25). The fourth most cited article was the study by $\mathrm{Xu}, \mathrm{Z}$. et al. titled "Pathological findings of COVID-19 associated with acute respiratory distress syndrome" and published in Lancet Respiratory 
Medicine's journal in 2020 (28). When the articles were assessed according to the number of citations per year, the most useful article was that of Xu, Z. et al. (2020) (28). The second most effective article was by $\mathrm{Wu}$ et al. (2020), titled "Risk factors associated with acute respiratory distress syndrome and death in patients with coronavirus disease 2019 pneumonia in Wuhan, China" and published in JAMA Internal Medicine (29). The most influential studies after the ones mentioned above were found respectively as those by Ranieri et al., Brower et al., Bellani et al., Ranucci et al., Guerin et al., and Cavalli et al. (2,6,7,27,30,31). The first 11 articles receiving the highest number of co-citations were confirmed respectively as follows: Bernard (1994), Ranieri (2012), Brower (2000), Murray (1988), Ashbaugh (1967), Ware (2000), Rubenfeld (2005), Bellani (2016), Amato (1998), Knaus (1985), and Guerin (2013) (1,2,6,7,21-27). It can be recommended for the researchers and clinicians interested in this subject to read these articles.

When the keyword analysis findings were evaluated, it was seen that there emerged 6 clusters as a result of cluster analysis. When studies conducted until today were evaluated in the literature, the subjects could be said to have clustered around mechanical ventilationprone position, sepsis, pneumonia, pediatric-ECMO, mortality-epidemiology, and COVID-19.

According to the result of trend keyword analysis, the most studied keywords in recent years were determined as SARS-COV-2, COVID-19, electrical impedance tomography, Berlin definition, transpulmonary pressure, driving pressure, pediatric biomarkers, and inflammation. The most cited keywords were cytokines, epidemiology, high-frequency ventilation, intensive care, meta-analysis, diagnosis, prognosis, and multiple organ failure.

Scanning of the literature revealed only two different bibliometric studies on the treatment of ARDS and the topic of ALI/ARDS. Wang et al. (2020) focused on only studies regarding the treatment of ARDS (32). Wang et al. (2020) analyzed a 10-year process (2009-2019) on ALI and ARDS (33). This study that we conducted is more comprehensive in terms of the publishing process and statistical analyses than the studies in the literature. The study analyzed the period between 1980 and 2020 and evaluated the citations, co-citations, keyword analyses, and world countries cooperation analyses thoroughly.

A limitation of the study is that we only used the WoS index. PubMed was not preferred since citation and cocitation analyses cannot be performed on the PubMed database. Scopus database indexes low-impact journals. WoS database is preferred more for bibliometric analysis since it indexes articles published in highimpact journals $(15,17)$. WoS database has been used in most of the studies conducted recently in the literature (8-19).

In this comprehensive study we conducted on ARDS, a topic that seems to be studied with many articles day by day, a summarized information of 5402 articles published between 1980 and 2020 was presented. A marked increase could be observed in the number of studies in the last two years with the effect of COVID19. We think that the number of studies has increased due to other systemic involvement of COVID-19 and these studies should be examined bibliometrically. In this context, we think that the relationship between COVID-19 and diseases such as cerebrovascular disease, coronary artery disease can be investigated bibliometrically. Countries with the most significant contribution to ARDS were the USA, Germany, France, and China. Critical Care Medicine published the highest number of articles. The journal receiving the most citations per article was the New England Journal of Medicine. We believe that this present article will be a useful guide to clinicians and researchers on the subject regarding the global output of ARDS.

Conflict of Interest: The authors declare that there is no conflict of interest regarding the publication of this article. 
Support and Acknowledgment: There is no financial support for this study.

Researchers' Contribution Rate Statement: Authors declare that they have contributed equally to the article Ethics Committe Aproval: No-need ethic approval.

\section{REFERENCES}

1. Máca J, Jor O, Holub M, Sklienka P, Burša F, Burda $\mathrm{M}$ at al. Past and present ARDS mortality rates: a systematic review. Respir Care. 2017;62(1):113-22.

2. Force ADT, Ranieri V, Rubenfeld G, Thompson B, Ferguson N, Caldwell E. Acute respiratory distress syndrome. JAMA. 2012;307(23):2526-33.

3. Camporota L, Ranieri VM. What's new in the" Berlin" definition of acute respiratory distress syndrome? Minerva Anestesiologica. 2012;78(10):1162-6.

4. Wang D, Hu B, Hu C, Zhu F, Liu X, Zhang J et al. Clinical characteristics of 138 hospitalized patients with 2019 novel coronavirus-infected pneumonia in Wuhan, China. JAMA. 2020;323(11):1061-9.

5. Squara P, Dhainaut J-F, Artigas A, Carlet J. Hemodynamic profile in severe ARDS: results of the European Collaborative ARDS Study. Intensive Care Medicine. 1998;24(10):1018-28.

6. Network ARDS. Ventilation with lower tidal volumes as compared with traditional tidal volumes for acute lung injury and the acute respiratory distress syndrome. New England Journal of Medicine. 2000;342(18):1301-8.

7. Bellani G, Laffey JG, Pham T, Fan E, Brochard L, Esteban A et al. Epidemiology, patterns of care, and mortality for patients with acute respiratory distress syndrome in intensive care units in 50 countries. JAMA. 2016;315(8):788-800.

8. Golpinar M, Demir E. Global research output of the cerebellum: Yesterday, today, and tomorrow.
Journal of the Anatomical Society of India. 2020;69(3):155-65.

9. Muslu Ü, Demir E. Development of rhinoplasty: yesterday and today. Med Sci. 2019;23(97):294-301.

10. Doğan G. The effect of religious beliefs on the publication productivity of countries in circumcision: a comprehensive bibliometric view. Journal of Religion and Health. 2020:59(2)1126-36.

11. Demir E, Comba A. The evolution of celiac disease publications: a holistic approach with bibliometric analysis. Irish Journal of Medical Science (1971-) 2020;189(1):267-76.

12. Doğan G, Kayır S. Global scientific outputs of brain death publications and evaluation according to the religions of countries. Journal of Religion and Health. 2020;59(1):96-112.

13. Demir E, Yaşar E, Özkoçak V, Yıldırım E. The evolution of the field of legal medicine: A holistic investigation of global outputs with bibliometric analysis. J Forensic Leg Med. 2020;69:101885.

14. Doğan G, İpek H. The development of necrotizing enterocolitis publications: a holistic evolution of global literature with bibliometric analysis. European Journal of Pediatric Surgery. 2020;30(03):293-303.

15. Kiraz M, Demir E. A Bibliometric analysis of publications on spinal cord injury during 19802018. World Neurosurgery. 2020;136:e504-e513.

16. Doğan G, İpek H. The evolution of hypospadias publications: A bibliometric approach. Rev Int Androl. 2020:S1698-031X(20)30023-6.

17. Demir E, Akmeşe Ö, Erbay H, Taylan-Özkan A, Mumcuoğlu K. Bibliometric analysis of publications on house dust mites during 1980-2018. Allergologia Et Immunopathologia. 2020;48(4):374-83.

18. Doğan G, Karaca O. A bibliometric analysis of the field of anesthesia during 2009-2018. Revista Brasileira de Anestesiologia 2020;70(2):140-52. 
19. Karaca O, Guldogan CE. A bibliometric analysis of publications on trauma in critical care medicine during 1980-2018: a holistic view. Turkish Journal of Trauma and Emergency Surgery. 2020;26(2):28795.

20. Van Eck NJ, Waltman L. Software survey: VOSviewer, a computer program for bibliometric mapping. Scientometrics. 2010;84(2):523-38.

21. Murray JF, Matthay MA, Luce JM, Flick MR. An expanded definition of the adult respiratory distress syndrome. Am Rev Respir Dis. 1988;138(3):720-3.

22. Ashbaugh D, Bigelow DB, Petty T, Levine B. Acute respiratory distress in adults. The Lancet. 1967;290(7511):319-23.

23. Ware LB, Matthay MA. The acute respiratory distress syndrome. New England Journal of Medicine. 2000;342(18):1334-49.

24. Rubenfeld GD, Caldwell E, Peabody E, Weaver J, Martin DP, Neff M et al. Incidence and outcomes of acute lung injury. New England Journal of Medicine. 2005;353(16):1685-93.

25. Amato MBP, Barbas CSV, Medeiros DM, Magaldi RB, Schettino GP, Lorenzi-Filho G et al. Effect of a protective-ventilation strategy on mortality in the acute respiratory distress syndrome. New England Journal of Medicine. 1998;338(6):347-54.

26. Knaus WA, Draper EA, Wagner DP, Zimmerman JE. APACHE II-A Severity of disease classification system: Reply. Critical Care Medicine. 1985;13(10):818-29.

27. Guérin C, Reignier J, Richard J-C, Beuret P, Gacouin A, Boulain $\mathrm{T}$ et al. Prone positioning in severe acute respiratory distress syndrome. New England Journal of Medicine. 2013;368(23):215968.

28. Xu Z, Shi L, Wang Y, Zhang J, Huang L, Zhang C et al. Pathological findings of COVID-19 associated with acute respiratory distress syndrome. Lancet Respir Med. 2020;8(4):420-22.
29. Wu C, Chen X, Cai Y, Zhou X, Xu S, Huang H et al. Risk factors associated with acute respiratory distress syndrome and death in patients with coronavirus disease 2019 pneumonia in Wuhan, China. JAMA Internal Medicine 2020;180(7):93443.

30. Ranucci M, Ballotta A, Di Dedda U, Bayshnikova E, Dei Poli M, Resta M et al. The procoagulant pattern of patients with COVID-19 acute respiratory distress syndrome. J Thromb Haemost. 2020;18(7):1747-51.

31. Cavalli G, De Luca G, Campochiaro C, Della-Torre E, Ripa M, Canetti D et al. Interleukin-1 blockade with high-dose anakinra in patients with COVID-19, acute respiratory distress syndrome, and hyperinflammation: a retrospective cohort study. The Lancet Rheumatology. 2020;2(6):e325-e331.

32. Wang Z-Y, Zhou Z-C, Zheng J, Cong Z-K, Zhu X. Bibliometric analysis of literature on acute respiratory distress syndrome treatments published between 2000 and 2019. Preprint (Version 1) available at Research Square: 16 December 2020. Doi: https://doi.org/10.21203/rs.3.rs-127680/v1

33. Wang C, Wang X, Long X, Xia D, Ben D, Wang Y. Publication trends of research on acute lung injury and acute respiration distress syndrome during 20092019: a 10-year bibliometric analysis. Am J Transl Res. 2020;12(10):6366-80. 